\title{
Efektivitas Fraud Triangle dalam Mendeteksi Manajemen Laba Akrual Berbasis SAS NO. 99 pada Perusahaan Penanaman Modal Asing
}

\section{Umarsono $^{1}$}

${ }^{1}$ Universitas Pancasila, Jl. Raya Lenteng Agunug, Jagakarsa, Jakarta Selatan, 12640.

\section{N F O A R T I K E L JEL Classification: M41}

\section{Keywords:}

fraud triangle, financial target, financial stability, nature of industry, change in audit and rationalization, accrual earnings management.

\section{A B S T R AC T}

Fraudulence on presentation of financial statements often made by the management through accrual earnings management. This study aimed to analyze the financial targets, financial stability, the nature of the industry, changes in auditors and rationalization of accrual earnings management. The research sample used is a total of 210 companies with foreign ownership. The results showed that the variables of financial targets proxy by ROA (Return on Assets), financial stability is proxied SATA (ratio of sales to total assets) and the rationalization of the variables indicated by audchange (turn of the public accounting firm), and the ratio of the change in total accrual of total assets proved to have influence significant akkrual earnings management. While the nature of the industry which is proxied by the ratio of change in receivables is not proven effect on accrual earnings management.

\section{A B S T R A K}

Kecurangan penyajian laporan keuangan banyak dilakukan oleh manajemen melalui manajemen laba akrual. Penelitian ini bertujuan untuk menganalisis financial target, financial stability, nature of industry, change in auditor dan rationalization terhadap manajemen laba akrual. Sampel penelitian yang digunakan adalah sebanyak 210 perusahaan penanaman modal asing. Hasil penelitian menunjukkan bahwa variabel financial target yang diproksikan dengan ROA (Return On Asset), financial stability yang diproksikan SATA ( rasio sales terhadap total asset) dan variabel rationalization yang diproksikan dengan $A U D C H A N G E$ ( pergantian kantor akuntan publik), dan rasio perubahan total akrual terhadap total asset terbukti berpengaruh signifikan terhadap manajemen laba akkrual., sedangkan nature of industry yang diproksikan dengan rasio perubahan piutang tidak terbukti berpengaruh terhadap manajemen laba akrual.

\section{Pendahuluan}

Laporan keuangan menjadi instrumen penting dalam memberikan informasi mengenai posisi keuangan, kinerja keuangan dan arus kas entitas yang dapat dipergunakan untuk pengambilan keputusan ekonomi. Laporan keuangan juga mencerminkan hasil pertanggungjawaban manajemen atas aktifitas dalam mengolah sumber daya yang dipercayakan kepada mereka.

Kompenen Laporan keuangan yang diterap-kan di Indonesia sudah semakin komprehensif. Akan tetapi masih banyak celah 
yang dapat menjadi ruang bagi manajemen dan oknum tertentu untuk melakukan kecurangan (fraud) dalam penyajian laporan keuangan. Pelanggaran yang dilakukan oleh emiten di pasar modal merupakan bukti bahwa diperlukan pengawasan yang cukup efektif oleh Otoritas Jasa Keuangan (OJK). Sebagai otoritas pengawas bursa, Otoritas Jasa Keuangan telah mengeluarkan berbagai aturan untuk melindungi kepentingan investor dan menjaga sistem perdagangan yang transparan dan fair. Namun demikian dalam praktiknya masih banyak pelanggaran aturan Otoritas Jasa Keuangan. Akibatnya, berbagai sanksi tindakan dikenakan oleh Otoritas Jasa Keuangan terhadap para emiten yang membandel. Kasus yang berkaitan dengan keterbukaan emiten dan perusahaan publik antara lain dugaan pelanggaran atas transaksi yang mengandung perbedaan kepentingan, informasi atau fakta yang harus segera diumumkan kepada publik, penyajian laporan keuangan, penggunaan dana hasil penawaran umum dan lain-lain. Sanksi yang dikenakan beragam tergantung kepada jenis dan intensitas pelanggaran itu sendiri. Pelanggaran yang bersifat administratif biasanya dikenakan sanksi berupa denda. Sedangkan pelanggaran yang relatif lebih berat seperti pelanggaran tindak pidana akan dikenakan tindakan hukum.

Hingga 13 Agustus 2014 Otoritas Jasa Keuangan (OJK) telah 75 kali melakukan pemeriksaan di pasar modal. Pemeriksaan ter-hadap 37 Emiten atau perusahaan publik atas dugaan kecurangan laporan keuangan, pelanggaran dan perencanaan RUPS, dan pelanggaran umum efek bersifat ekuitas. 34 pemeriksaan terkait transaksi dan lembaga efek dengan dugaan terhadap ketentuan pengendalian internal perusahaan efek dan indikasi pergerakan harga saham yang tidak wajar di Bursa Efek Indonesia (BEI). Menurut Kepala Eksekutif Pengawas Pasar Modal (OJK), Nurhaida 4 pemeriksaan terkait pengelolaan investasi dengan dugaan pelanggaran mengenai pedoman pengelolaan reksa dana berbentuk kontrak investasi kolektif. Otoritas Jasa Keuangan (OJK) telah menjatuhkan sanksi kepada 316 pelaku pasar modal. Terdiri dari 32 sanksi tertulis, 280 denda, 2 pembekuan izin usaha, dan 2 pencabutan izin usaha. Pencabutan izin usaha diberlakukan kepada penasehat investasi karena keterlambatan penyampaian laporan berkala dan wakil perantara pedagang efek karena kasus pelanggaran dibidang pasar modal. Sementara pembekuan izin dikenakan kepada wakil perusahaan efek dan seorang akuntan publik. Otoritas Jasa Keuangan juga masih memproses pengenaan sanksi kepada 87 pelaku pasar modal lantaran terlambat menyampaikan laporan keuangan. Adapun enam diantaranya kasus pelanggaran ketentuan disektor pasar modal.

Menurut pendekatan Fraud Triangle (Cressey, 1953), suatu kecurangan akan muncul sebagai akibat tiga kondisi, yaitu tekanan,peluang dan rasionalisasi. Bermacam skandal korporasi yang muncul dalam beberapa tahun terakhir telah menunjukkan betapa manajemen perusahaan memiliki ambisi untuk memuaskan ekspektasi utilitas mereka sendiri dalam memaksimumkan keuntungan dengan mengorbankan fihak lain. Enron Corp., perusahaan terbesar ketujuh di AS yang bergerak dibidang industry energy, manajemen perusahaan Enron telah melakukan kecurangan laporan keuangannya untuk memperoleh kompensasi moneter yang besar.

Dalam prinsip akuntansi yang berlaku umum (PABU) fleksibilitass memacu manajemen melakukan diskresi dalam akuntansi akrual. Diskresi manajerial tersebut dapat meningkatkan informasi laba yang cenderung direkayasa karena dimungkinkan adanya informasi privat yang disebut effisient earnings management (EEM). Disisi lain, adanya perbedaan insentif antara manajer dan pemegang saham mengakibatkan manajer menggunakan fleksibilitas yang diperbolehkan dalam PABU untuk melakukan manajemen laba akrual sehingga menciptakan distorsi dalam laporan keuangan yang dilaporkan yang disebut opportunistic earnings management. Melihat fenomena adanya research gap dan inkonsistensi hasil penelitianpenelitian terdahulu, menjadi lebih tertarik untuk melakukan penelitian lebih mendalam tentang faktor-faktor yang mempengaruhi fraud triangle dalam mendeteksi manajemen laba akrual pada 
perusahaan Penanaman Modal Asing yang tercatat di Bursa Effek Indonesia dari tahun 20102014. Penggunaan analisis fraud triangle untuk mendeteksi adanya kecurangan dalam laporan keuangan sebelumnya pernah dilakukan antara lain oleh Cressey (1953), Turner et al. (2003), Lou dan Wang (2009), Skousen et al. (2009), Martyanta dan Daljono (2013), Kusumawardhani (2013), Ansar (2011), Kurniawati dan Raharja (2012). Selain itu ada beberapa penelitian yang menambahkan variable diluar konsep fraud triangle yaitu penelitian Subroto (2012), menambahkan karakteristik auditor eksternal serta penelitian Rini dan Achmad (2012).

Penelitian Skousen et al, (2009) bertujuan untuk menguji efektivitas pengadobsian fraud risk factor framework oleh Cressey (1953) dalam SAS No. 99 untuk mendeteksi adanya manajemen laba akrual. Penelitian ini menggunakan variable - variabel yang berasal dari pengembangan fraud triangle (pressure, opportunity dan razionalization) yaitu financial target, financial stability, nature of industry, razionalization (audit change) dan rationalization (total akrual). Dari variabel - variabel tersebut selanjutnya ditentukan proksi-proksi pengukurannya. Dalam penelitian ini digunakan metode regresi linier berganda.

Menurut Etgina (2013), fraud dalam pelaporan keuangan biasanya dilakukan karena adanya tekanan (pressure) berupa ekspektasi terhadap prestasi kerja manajemen. Oleh sebab itu fraud seperti ini dinamakan fraud manajemen atau jenis fraud yang dilakukan untuk kepentingan manajemen. Fenomena ini diperkuat oleh hasil penelitian yang dilakukan oleh $A C F E$ (Association of Certified Fraud Exeminers) dalam Nabila (2013). Menunjukkan bahwa 58\% dari kasus kecurangan yang dilaporkan dilakukan oleh karyawan tingkat manajerial, 36\% dilakukan oleh manajer tanpa melibatkan orang lain, dan $6 \%$ dilakukan oleh manajer dengan melakukan kolusi bersama karyawan.

Menurut Association of Certified Fraud Examiners ( $A C F E$ ), fraud dalam hubungan kerja memiliki tiga cabang utama, yaitu fraudulent financial reporting, assets misapropriation dan
Corruption. Masing-masing cabang tersebut selanjutnya masih akan terbagi-bagi lagi menjadi beberapa ranting dan anak ranting yang lebih spesifik. Pembagian cabang-cabang, ranting dan anak ranting fraud tersebut digambarkan dalam bentuk bagan yang biasa disebut dengan fraud tree.

Lou dan Wang (2009) mengatakan bahwa selama dua dekade terakhir, minat dari praktisi dan akademisi dibidang kecurangan laporan keuangan telah meningkat secara dramatis. Corporate fraud secara umum masuk pada salah satu dari tiga kategori berikut ini, yaitu : penyalahgunaan aset, kecurangan laporan keuangan dan korupsi ( Ernst \& Young LLp. 2009). Pada dekade ini banyak skandal akuntansi yang menyebabkan pihak berspekulasi bahwa manajemen telah melakukan tindakan kecurangan dalam laporan keuangan mereka. Jika masalah kecurangan laporan keuangan masalah yang signifikan, profesi audit seharusnya secara effektif mampu mendeteksi aktivitas kecurangan tersebut sebelum menjadi skandal (Skousen et al.,2009).

Menurut SAS no. 99 terdapat empat jenis tekanan yangmenyebabkan terjadinyakecurangan pada laporan keuangan. Jenis tekanan tersebut adalah financial stability, external pressure. personal financial need dan financial target. Mengklasifikasi peluang yang mungkin terjadi kedalam tiga kategori yaitu nature of industry, ineffective monitoring dan organizational structure. Sedangkan rasionalisasi bagian ketiga dari fraud triangle yang sangat sulit diukur. Kegagalan audit dan litigasi meningkat dengan cepat setelah adanya pergantian auditor (Stice, 1991: St Pierre \& Anderson, 1984; Loebbeckeetal, 1989) maka pergantian auditor (AUDCHANGE) disertakan sebagai proksi rasionalisasi dalam mendeteksi kecurangan laporan keuangan (Skousen et al.,2009).

Kusumawardhani (2013) melakukan penelitian menggunakan fraud triangle dalam pendekteksian fraudulent financial reporting. Penelitian dilakukan kepada perusahaan perbankan yang terdaftar di BEI pada tahun 2010 dan 2011. Penelitian ini menggunakan variablevariabel yang merupakan pengembangan dari 
fraud triangle yaitu financial stability, personal financial need, dan inefective monitoring dalam mendeteksi terjadinya manajemen laba akrual. Dari penelitian tersebut diperoleh hasil bahwa financial stability dan inefektive monitoring berpengaruh terhadap pendeteksian manajemen laba akrual.

Skousen dan Twedt (2009) melakukan penelitian terhadap perusahaan-perusahaan di 22 negara berkembang dengan mengkategorikan perusahaan-perusahaan dalam 9 sektor utama dan membandingkannya dengan perusahaanperusahaan yang terdapat di Amerika Serikat. Penelitian tersebut menunjukkan bahwa Amerika Serikat sebagai benchmark masuk dalam 11 negara dengan nilai standar deviasi yang rendah.

David T Wolfe dan Hermanson (2004) mengemukan bahwa fraud triangle dapat dikembangkan untuk meningkatkan upaya pencegahan dan deteksi fraud dengan memperhitungkan elemen keempat yaitu capability atau kemampuan individu. Individual capability memegang peranan penting dimana fraud dapat saja terjadi bersamaan dengan ketiga faktor fraud triangle.

Penelitian lain, seperti studi yang dilakukan di Taiwan oleh Yung-I Lou dan Ming-Long Wang (2009), studi ini membahas mengenai faktor risiko fraud berdasarkan konsep fraud triangle atau segitiga kecurangan terhadap manajemen laba akrual. Penelitian ini menemukan bahwa tekanan keuangan dari perusahaan, rasio tinggi dari transaksi yang kompleks, integritas manajer perusahaan dan hubungan dengan perusahaan auditor berpengaruh terhadap pendeteksi fraud pada pelaporan keuangan. Penelitian ini menunjukkan bahwa variabel dalam fraud triangle dapat digunakan untuk mendeteksi kecurangan laporan keuangan pada perusahaan yang berada di Taiwan.

Antonius Stanny (2011) meneliti faktor resikoyang mempengaruhifraud pada kecurangan pelaporan keuangaan pada perusahaan publik di Indonesia. Penelitian ini menemukan bahwa stabilitas keuangan, tekanan eksternal dan tekanan finansial pribadi yang merupakan bagian faktor risiko dari tekanan berpengaruh terhadap pendeteksian manajemen laba akrual. Faktor resiko dari peluang atau kesempatan seperti faktor risiko dari kondisi industri dan kompleksitas struktur organisasi berpengaruh terhadap pendeteksian manajemen laba akrual sedangkan ketidakefektifan pengawasan berpengaruh terhadap pendeteksian manajemen laba akrual. Faktor resiko dari rasionalisasi seperti praktek akuntansi agresif dan hubungan auditor berpengaruh terhadap pendeteksian manajemen laba akrual.

Daniel dan Niki (2013) meneliti mengenai pendeteksian manajemen laba akrual dengan menggunakan fraud triangle atau segitiga kecurangan. Penelitian ini menemukan bahwa stabilitas keuangan, target keuangan dan komisaris independen berpengaruh dalam mendeteksi terjadinya manajemen laba akrual. Sedangkan faktor resiko dari tekanan yaitu tekanan eksternal tidak berpengaruh terhadap pendeteksian manajemen laba akrual. Penelitian Daniel dan Niki hampir sama dengan penelitian yang dilakukan oleh Lou dan Wang (2009) yang menunjukan bahwa variabel fraud triangle dapat digunakan untuk mendeteksi terhadap terjadinya manajemen laba akrual

\section{Telaah Teori dan Pengembangan Hipotesis}

Teori keagenan (Agency theory) adalah teori tentang aktivitas perusahaan yang mendasari praktik bisnis diantara fihak-fihak yang memeliki kepentingan untuk mencapai tujuan. Teori keagenan suatu model kontraktual antara dua atau lebih pihak, dimana salah satu fihak disebut agen dan dilain fihak disebut prinsipal. Teori tersebut berakar dari sinergi teori ekonomi, teori keputusan, teori sosiologi dan teori organisasi.

Jensen and Mecking (1976) bahwa agency theory mendeskripsikan bahwa pemegang saham sebagai prisipal dan manajemen sebagai agen. Pemegang saham mendelegasikan pengambilan keputusan bisnis kepada manajemen perusahaan yang merupakan perwakilan atau agen dari pemegang saham.

Manajemen laba akrual adalah sebagai suatu intervensi terhadap proses pelaporan 
keuangan eksternal untuk memperoleh beberapa keuntungan pribadi maupun organisasi. Healy (1985) menjelaskan bahwa terdapat beberapa cara yang digunakan oleh manajemen untuk melakukan earning management, salah satu cara adalah dengan mengendalikan transaksi akrual.

Fraud jarang diperhatikan oleh masyarakat kita pada umumnya, meskipun banyak media cetak dan elektronik memuat berbagai berita tentang fraud. The Association of Certified Fraud Examiners (ACFE), fraud adalah: "Perbuatan-perbuatan yang melawan hukum yang dilakukan dengan sengaja untuk tujuan tertentu, dilakukan orang-orang dari dalam atau luar organisasi untuk mendapatkan keuntungan pribadi ataupun kelompok yang secara langsung atau tidak langsung merugikan pihak lain.

Secara skematis ACFE (Association of Certified Fraud Examiners) mengklasifikasikan fraud (kecurangan) yang dikenal dengan istilah fraud tree. Pohon ini menggambarkan cabangcabang dari fraud dalam bentuk skema hubungan kerja beserta ranting dan anak rantingnya. Occupational tree ini mempunyai tiga cabang utama, yaitu corruption, asset missappropriation dan fraudulent financial reporting.

\section{Uniform Occupational Fraud Classification System}

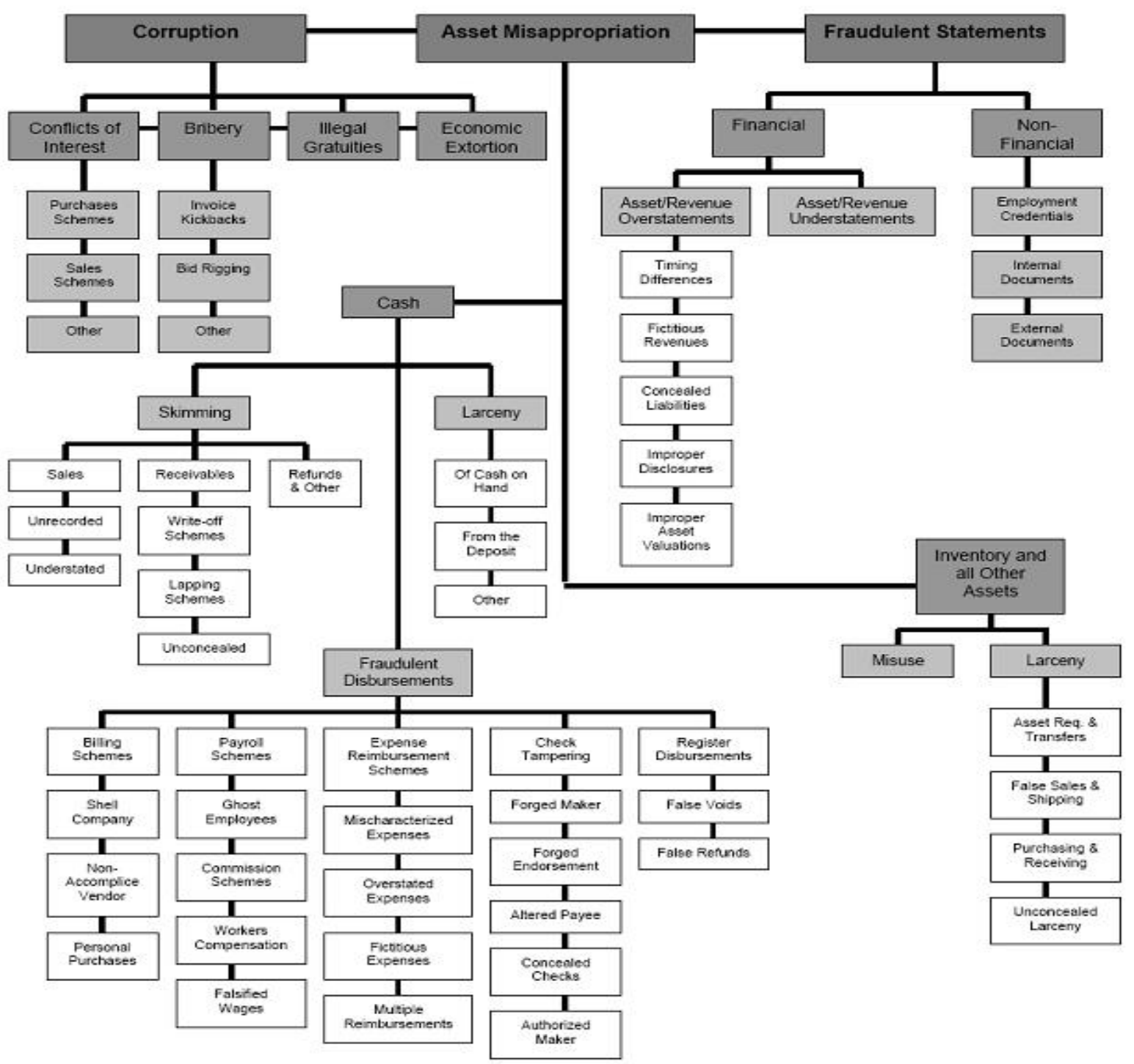

Sumber: ACFE

Gambar 1. Uniform Occupational Fraud Classification System 
Statement on Auditing Standards No. 99 mendefinisikan fraud sebagai "an intentional act that result in a material misstatement in financial statements that are the subject of an audit. Konsep segitiga kecurangan (fraud triangle) merupakan suatu gagasan yang meneliti tentang penyebab terjadinya kecurangan. Gagasan ini pertama kali dicetuskan oleh Donald R. Cressey (1953) yang dinamakan fraud triangle . all., (2013). Ketiga faktor tersebut digambarkan dalam segitiga kecurangan (fraud triangle), seperti nampak pada gambar .

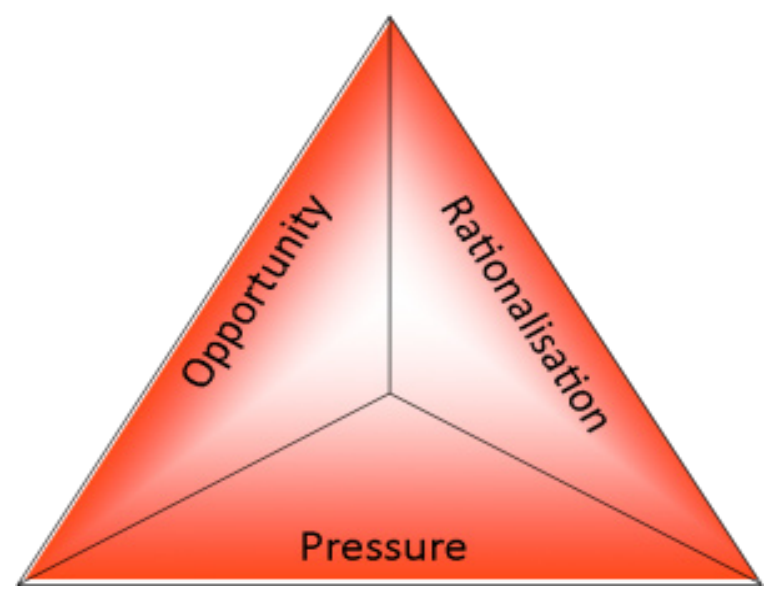

Gambar 1

Fraud Triangle Theory oleh Cressey (1953)

Pressure (tekanan) adalah tekanan pada seseorang untuk melakukan kecurangan dengan memanfatkan berbagai kesempatan untuk melakukan fraud. Financial target adalah suatu tingkat kinerja laba yang akan dicapai atas usaha yang dilakukan oleh perusahaan. Financial target diproksikan dengan ROA (Return On Assets) dengan rumus:

$$
\text { ROA }=\frac{\text { Laba Setelah Pajak t-1 }}{\text { Total Asset t-1 }}
$$

Financial Stability; Menurut SAS No. 99, manajer menghadapi tekanan untuk melakukan kecurangan laporan keuangan ketika stabilitas keuangan atau profitabilitas terancam oleh keadaaan ekonomi, industri, atau situasi entitas yang beroperasi (Skousen et al., 2009). Rasio perubahan total aset dijadikan proksi pada variabel Financial Stability dengan rumus :

\section{Sales \\ SATA $=$ Total Asset}

Opportunity adalah peluang memungkinkan seseorang melakukan fraud. Nature of industry adalah berkaitan metode yang digunakan untuk menentukan cadangan piutang yang tidak dapat ditagih. Oleh karena itu nature of industry diproksikan dengan rasio total piutang dengan rumus :

\section{Receivable $=\frac{\text { Receivable } \mathrm{t}}{\text { Sales } \mathrm{t}}-\frac{\text { Receivable } \mathrm{t}-1}{\text { Sales } \mathrm{t}-1}$ \\ Change in auditor pada suatu} perusahaan dapat dinilai sebagai suatu upaya untuk menghilangkan yang ditemukan oleh auditor sebelumnya. Oleh karena itu, penelitian ini memproksikan Rationalization dengan pergantian kantor akuntan publik $(\triangle \mathrm{CPA})$ dengan variabel dummy. dimana apabila terdapat perubahan kode 1 , apabila tidak diberi kode 0 . Rumus

\section{Total Akrual}

$$
\text { Rationalization }=\overline{\text { Total Aktiva }}
$$

Pengaruh Financial Target, Financial Stability, Natur Of Industry, Audit Change dan Total Akrual terhadap Manajemen Laba Akrual pada Perusahaan yang tercatat di Bursa Efek Indonesia tahun 2010-2014. Berdasarkan kajian teori riset ini menguji 4 hipotesis penelitian meliputi pengaruh financial target, financial stability, natur of industry, dan audit change terhadap manajemen laba akrual.

\section{Financial target dan deteksi manajemen laba akrual}

Dalam menjalankan operasional perusahaan, manajemen dituntut untuk mencapai performa terbaik sehingga dapat mencapai target keuangan yang telah direncanakan. Perbandingan laba tehadap jumlah aktiva atau Return on Asset adalah ukuran kinerja operasional yang banyak digunakan untuk menunjukkan seberapa efisien aktiva telah bekerja (Skousen et al., 2009). 
Return On Asset digunakan untuk mengukur manajemen perusahaan dalam memperoleh keuntungan (laba) secara keseluruhan. Semakin besar ROA yang diperoleh, semakin besar pula tingkat keuntungan yang dicapai oleh perusahaan tersebut dan semakin baik pula posisi perusahaan tersebut dari segi penggunaan aset (Dendawijaya, 2005).

Penelitian Carlson dan Bathala (1997) dalam Widyastuti (2009) membuktikan bahwa perusahaan yang memiliki laba yang besar (diukur dengan profitabilitas atau ROA) lebih mungkin melakukan manajemen laba daripada perusahaan yang memiliki laba yang kecil.

Akan tetapi, hasil penelitian dari Skousen et al. (2009) tidak menguatkan bukti bahwa ROA berpengaruh terhadap manajemen laba akrual. Penelitian ini mencoba membuktikan bahwa ROA berpengaruh terhadap manajemen laba akrual. Berdasarkan uraian tersebut, diajukan hipotesis penelitian sebagai berikut:

\section{H1: Variabel financial target berpengaruh terhadap manajemen laba akrual.}

\section{Variabel fianancial stability dan deteksi manajemen laba akrual.}

Ketika suatu perusahaan berada dalam kondisi stabil maka nilai perusahaan akan naik dalam pandangan investor, kreditor, dan publik. MenurutSASNo.99, manajermenghadapitekanan untuk melakukan kecurangan laporan keuangan ketika stabilitas keuangan dan/atau profitabilitas yang terancam oleh keadaaan ekonomi, industri, atau situasi entitas yang beroperasi (Skousen et al., 2009). Loebbecke $d k k$. (1989) Bell et al. (1991) menunjukkan bahwa dalam kasus dimana perusahaan mengalami pertumbuhan yang berada di bawah rata-rata industri, manajemen akan memanipulasi laporan keuangan untuk meningkatkan prospek perusahaan (Skousen et al., 2009).

Perusahaan berusaha untuk meningkatkan outlook perusahaan yang baik salah satunya dengan memanipulasi informasi kekayaan aset yang dimilikinya. Bentuk manipulasi pada laporan keuangan yang dilakukan oleh manajemen berkaitan dengan pertumbuhan aset perusahaan (Skousen et al., 2009). Oleh karena itu, rasio perubahan total aset dijadikan proksi pada variabel Financial Stability. Semakin tinggi total aset yang dimiliki perusahaan menunjukkan kekayaan yang dimiliki semakin banyak. Penelitian yang dilakukan oleh Skousen et al. (2009) membuktikan bahwa semakin besar rasio perubahan total aset suatu perusahaan maka probabilitas dilakukannya tindak kecurangan pada laporan keuangan perusahaan tersebut semakin tinggi. Berdasarkan uraian tersebut, diajukan hipotesis penelitian sebagai berikut. Berdasarkan uraian tersebut, diajukan hipotesis penelitian sebagai berikut:

\section{H2: Variabel financial stability berpengaruh} terhadap manajemen laba akrual.

\section{Variabel natur of industry sebagai variabel} untuk mendeteksi manajemen laba akrual.

Piutang dan persediaan memerlukan penilaian subjektif dalam memperkirakan tidak tertagihnyapiutangdanobsoleteinventory. Mereka menyarankan bahwa karena adanya penilaian subjektif dalam menentukan nilai dari perkiraan tersebut, manajemen dapat menggunakan perkiraan tersebut sebagai alat untuk manipulasi laporan keuangan. Argumen ini didukung oleh Loebbecke et al. (1989), yang menemukan bahwa perkiraan piutang dan persediaan terlibat dalam sejumlah besar fraud dalam sampel mereka . Summers dan Sweeney (1998) meneliti perkiraan piutang dan persediaan, menemukan bahwa kondisi perkiraan persediaan dan piutang usaha berbeda antara perusahaan yang melakukan fraud dengan perusahaan yang tidak melakukan fraud. Summers dan Sweeney (1998) menggunakan proksi untuk nature of industry yang berkaitan dengan piutang adalah rasio perubahan dalam piutang usaha. Ukuran ini dihitung sebagai rasio piutang terhadap penjualan di tahun $t$ dikurangi dengan rasio piutang terhadap penjualan di tahun $\mathrm{t}-1$, di mana $\mathrm{t}$ adalah tahun sebelum terjadinya fraud. Berdasarkan uraian tersebut, diajukan hipotesis penelitian sebagai berikut:

H3 : Variabel nature of industry berpengaruh terhadap manajemen laba akrual. 


\section{Variabel change in Auditor dan deteksi manajemen laba akrual.}

Rationalization merupakan suatu faktor kualitatif yang tidak dapat dipisahakan dari terjadinya fraud. Studi yang dilakukan oleh Stice (1991) dan St Pierre dan Anderson (1984) menunjukkan bahwa perubahan auditor dapat terjadi karena alasan yang sah, risiko kegagalan audit dan litigasi berikutnya akan lebih tinggi dibandingkan tahun-tahun sebelumnya. Loebbecke et al. (1989) menemukan bahwa sejumlah besar fraud dalam sampel mereka dilakukan dalam dua tahun pertama masa jabatan auditor. Summers dan Sweeney (1998) berpendapat bahwa perubahan auditor tidak memiliki hubungan yang signifikan terhadap fraudulent financial reporting. Argumen Summers dan Sweeney tidak didukung oleh SAS No 99 atau Albrecht (2002), yang menyarankan perubahan auditor dikaitkan dengan fraudulent financial reporting. Penggantian Kantor akuntan publik dapat menjadi salah satu proksi dari rationalization (Skousen et al. 2009). Perubahan atau pergantian kantor akuntan publik yang dilakukan perusahaan dapat mengakibatkan masa transisi dan stress period melanda perusahaan. Adanya pergantian akuntan publik pada pada dua tahun periode dapat menjadi indikasi terjadinya fraud. Berdasarkan uraian tersebut, penelitian ini mengajukan hipotesis sebagai berikut:

\section{H4 : Variabel change in Auditor berpengaruh terhadap manajemen laba akrual.}

\section{Variabel rationalization dan deteksi manajemen} laba akrual.

Francis dan Krishnan (1999) dan Vermeer (2003) berpendapat bahwa prinsip akrual berhubungan dengan pengambilan keputusan manajemen dan memberikan wawasan terhadap rasionalisasi dalam pelaporan keuangan. Menurut Skousen (2009) variabel rasio total akrual dapat digunakan untuk menggambarkan rasionalisasi terkait dengan penggunaan prinsip akrual oleh manajemen. Total akrual dikalkulasikan sebagai perubahan asset lancar dikurang perubahan kas, dikurang perubahan kewajiban lancar ditambah perubahan utang jangka pendek dikurang beban depresiasi dan amortisasi dikurang pajak penghasilan yang ditangguhkan ditambah modal. Berdasarkan uraian tersebut, penelitian ini mengajukan hipotesis sebagai berikut :

H5 : Variabel rationalization berpengaruh terhadap manajemen laba akrual.

\section{Metode}

Dalam penelitian ini sampel yang diambil 120 Perusahaan Penanaman Modal Asing selama periode tahun 2010-2014. Metode pemilihan sampling pada penelitian ini adalah tehnik purposive sampling dengan kriteria sampel pada penelitian ini adalah sebagai berikut:

1. Perusahaan Penanaman Modal Asing tercatat di Bursa Efek Indonesia tahun 2010-2014 yang menerbitkan laporan keuangan tahunan (annual report) selama periode pengamatan.

2. Perusahaan secara konsisten menerbitkan laporan keuangan selama periode penelitian tahun 2010-2014.

Data yang digunakan dalam penelitian ini adalah laporan keuangan tahunan (annual report) yang bersumber dari informasi keuangan dari situs www.idx.co.id dan Indonesia Capital Market Directory (ICMD), perusahaan penanaman modal asing periode Tahun 2010-2014.

Variabel yang dianalisis dalam penelitian ini terdiri dari enam variabel yang terdiri satu variabel dependen dan lima variabel independen. Variabel independen adalah financial target, financial stability, natur of industry, audit change dan total akrual. Sedangkan variabel dependen adalah manajemen laba akrual. Manajemen laba dapat diukur melalui discretionary accrual yang dihitung dengan cara menyelisihkan total accruals (TA) dan nondiscretionary accruals (NDA dengan Model Modified Jones Model (1995). Metode analisis ini digunakan dalam penelitian ini uji statitik deskriptif dan uji hipotesis dengan menggunakan regresi linier berganda

Tehnik yang digunakan dalam penelitian ini terdiri dari dua bagian, yaitu : (1) Pengujian asumsi klasik, dan (2) pengujian hipotesis penelitian. Pengujian asumsi klasik meliputi uji 
normalitas yang dilakukan untuk mengetahui apakah masing-masing variabel memiliki distribusi normal atau tidak. Normalitas dapat dideteksi dengan pengamatan melalui nilai residual. Normalitas residual model dalam bentuk unstandardize value pada penelitian dideteksi dengan menggunakan uji statistic KolmogorovSmirnov dengan cara melihat nilai probabilitas signifikan yang bernilai diatas 0,05 maka dapat dikatakan data berdistribusi normal. Selanjutnya uji. Auto korelasi dengan cara mendeteksi adanya gejala korelasi adanya gejala korelasi dengan melihat nilai Durbin-Watson (DW). Kemudian uji heteroskedastisitas, untuk mendeteksi ada tidaknya heteroskedastisitas dengan uji Gletsjer dilakukan dengan meregresi independen variabel dengan nilai absolute residual model sebagai variabel dependen Hasil yang menunjukkan tidak ada pengaruh siginifikan untuk masingmasing independen variabel terhadap absolute nilai residual model.

Pengujian model penelitian dilihat dari hasil uji koefisien determinasi. Hasil uji ini digunakan untuk mengetahui seberapa besar kemampuan variabel independen menjelaskan variabel dependen. Koefisien determinasi dapat dilihat pada nilai Adjusted $\mathrm{R}$ Square yang menunjukkan seberapa besar proporsi variabel independen yang dapat dijelaskan oleh variabel independen. Semakin tinggi nilai koefisien determinasi dapat menjadi indikator bahwa kemampuan menjelaskannya semakin besar model diasumsikan baik (fit). Uji signifikansi $t$, pengujian ini digunakan untuk membuktikan hipotesis penelitian $\mathrm{H} 1, \mathrm{H} 2, \mathrm{H} 3, \mathrm{H} 4$ dan $\mathrm{H} 5$. Kriteria penolakan hipotesis dengan $\alpha=5 \%$ ditentukan sebagai berikut Ho ditolak jika nilai probabilitas signifikansi $<5 \%$. Ho diterima jika nilai probabilitas signifikansi $\geq 5 \%$.

Pengujian model penelitian menggunakan uji F dan koefisien determinasi. Uji F merupakan pengujian mengetahui pengaruh seluruh variabel independen terhadap variabel dependen secara bersama-sama (simultan). Model dikatakan baik jika paling tidak dari satu variabel yang diuji berpengaruh terhadap variabel dependennya (Jogianto, 2007:142). Pembuktian terkait pernyataan tersebut dapat dilihat dari uji F, jika nilai $\alpha=5 \%$ maka model dapat dikatakan baik (fit) jika probabilitas basil signifikansinya $<0.05 \%$.

\section{Hasil Penelitian dan Pembahasan.}

Penelitian ini bertujuan melakukan analisis deteksi manajemen laba akrual melalui akun financial target, financial stability, nature of industry, change in auditor dan rationalization. Deskripsi variabel penelitian sebagaimana tampak pada tabel 1 .

\section{financial target (ROA)}

Hasil uji asumsi klasik menunjukkan tdk terjadi multikolinearitas $(\mathrm{VIF}<10)$ dan distribusi nilai residual normal $(0.162<0.05)$. Uji heteroskedastisitas dengan uji gletsjer menunjukkan secara umum tidak terjadi hetroskedastisitas, meskipun hal tersebut tidak berlaku untuk variabel ROA. hasil uji autokorelasi $(\mathrm{dw}=1,438)$ menunjukkan bahwa terjadi autokorelasi $(\mathrm{dU}, \mathrm{n}=120=1.79)$. Hasil uji regresi terangkum pada tabel 2.

Persamaan regresi hasil pengujian adalah sebagai berikut.

$$
\begin{aligned}
& \mathrm{DA}=0,133-0,147 \text { ROA-0,047 SATA+0,009 } \\
& \text { NOI +0,061 AUD+1,141 RAS }+€
\end{aligned}
$$

Tabel 1. Deskripsi Variabel

\begin{tabular}{ccccc}
\hline & Minimum & Maximum & Mean & $\begin{array}{c}\text { Std. } \\
\text { Deviation }\end{array}$ \\
\hline DA & $(0.211)$ & 1.036 & 0.047 & 0.136 \\
ROA & $(0.756)$ & 0.657 & 0.100 & 0.144 \\
SATA & 0.047 & 2.308 & 1.123 & 0.530 \\
NOI & 0.000 & 3.842 & 0.209 & 0.519 \\
AUD & 0.000 & 1.000 & 0.067 & 0.250 \\
RAS & $(0.591)$ & 0.474 & $(0.021)$ & 0.106 \\
\hline
\end{tabular}


Tabel 2. Rangkuman Hasil Pengujian

\begin{tabular}{lrrrr}
\hline Keterangan & \multicolumn{1}{l}{ B } & Std. Error & \multicolumn{1}{c}{ t-hitung } & \multicolumn{1}{c}{ Sig. } \\
\hline ROA & $-0,147$ & $0-, 147$ & $-2,940$ & 0,004 \\
SATA & $-0,047$ & $-0,047$ & $-3,573$ & 0,001 \\
NOI & 0,009 & 0,009 & 0,780 & 0,437 \\
AUD & 0,061 & 0,061 & 2,464 & 0,015 \\
RAS & 1,141 & 1,141 & 19,203 & 0,000 \\
Constant & 0,133 & 0,015 & & \\
R-Square & 0,783 & & & \\
Adjusted R-Square & 0,773 & & & \\
F-hitung & 82,148 & & & \\
Sig. F & 0,000 & & & \\
\hline
\end{tabular}

Diketahui nilai $\mathrm{F}$ hitung sebesar 82,148 dengan tingkat signifikansi 0,0000. Artinya financial target, financial stability, natur of industry, rationalization secara simultan berpengaruh signifikan terhadap manajemen laba akrual Nilai R Square ( R2) adalah 0,783 artinya $78,3 \%$ besarnya variasi variabel $(D A)$ dipengaruhi (ROA), (SATA), (NOI), ( AUDCHANGE) (TATA) sedangkan sisanya $21,7 \%$ dijelaskan oleh faktorfaktor lain yang tidak diteliti. Nerdasarkan hasil uji t hanya variabel NOI yang tidak berpengaruh terhadap manajemen laba.

Hasil penelitian ini menunjukkan bahwa financial target (ROA) merupakan perbandingan antara laba bersih setelah pajak dengan total asset, merupakan rasio yang mengukur kinerja operasional yang digunakan untuk mengetahui seberapa efisien aktiva telah bekerja. Return on asset sering digunakan dalam menilai kinerja manajer dalam menentukan besarnya bonus, kenaikan upah dan lain-lain.

(ROA) yang positif menunjukkan bahwa dari total aktiva yang dipergunakan untuk beroperasi, perusahaan mampu memberikan laba bagi perusahaan. Sebaliknya apabila return on assets yang negatif menunjukkan bahwa dari total aktiva yang dipergunakan, perusahaan mendapatkan kerugian. Jadi jika suatu perusahaan mempunyai ROA yang tinggi maka perusahaan tersebut berpeluang besar dalam meningkatkan pertumbuhan. Tetapi jika total aktiva yang digunakan perusahaan tidak memberikan laba maka perusahaan akan mengalami kerugian dan akan menghambat pertumbuhan.
Hipotesis pertama menyatakan financial target ( ROA)berpengaruhsignifikanterhadapmanajemen laba akrual diterima. Financial target ( $R O A$ ) yang berpengaruh signifikan terhadap perusahaan penanaman modal asing menandakan bahwa manajer perusahaan akan berusaha memenuhi target keuntungan yang telah direncanakan dengan melakukan praktik manajemen laba akrual. Motivasi manajer melakukan praktik manajemen laba antara lain informasi laba atau earnings banyak digunakan oleh para investor dan kreditur dalam mengambil keputusan investasi atau pemberian kredit. (Watts, Zimmerman 1986 dan Pamudji, Trihartati, 2010) menyatakan bahwa motivasi manajemen laba antara lain bonus plan hypothesis, debt (equity) hipothesis dan political cost hipothesis. Hasil penelitian ini konsisten dengan penelitian Deviana Rosita ( 2014) yang menyatakan financial target yang diproksikan dengan return on assets berpengaruh signifikan terhadap manajemen laba akrual.

Hipotesis kedua yang diajukan menyatakan ada pengaruh financial stability (SATA) terhadap manajemen laba akrual. Berdasarkan hasil pengujian hipotesis dengan menggunakan uji $\mathrm{t}$, secara parsial financial stabilityt (SATA) berpengaruh signifikan terhadap manajemen laba akrual pada perusahaan penanaman modal asing yang tercatat di Bursa Efek Indonesia (BEI).

Financial stability (SATA) adalah perbandingan antara total sales dengan total asset. Suatu kondisi dimana mekanisme ekonomi dalam menetapkan harga, alokasi dana dan pengelolaan risiko berfungsi secara baik dan mendukung 
pertumbuhan ekonomi (Bank Indonesia, 2013). Akan tetapi kondisi ketidakstabilan keuangan dapat dipicu dengan berbagai macam penyebab dan gejolak yang berasal dari kondisi ekonomi, politik dan industri. Adanya tekanan dari stabilitas keuangan pada kondisi bisnis entitas dapat diindikasikan oleh tingkat kompetisi usaha yang sengit, kerawanan yang tinggi terhadap perubahan yang sangat cepat, misalnya perubahan tehnologi, suku bunga bank, dan nilai tukar valuta asing. Menurunnya industri, kegagalan bisnis yang meningkat dan turunnya permintaan dari para pelanggan merupakan gambaran kondisi yang mempengaruhi stabilitas keuangan perusahaan. Hal inilah yang akhirnya menekan manajer untuk melakukan tindak kecurangan pada laporan keuangannya dengan praktik manajemen laba akrual.

Hipotesis kedua menyatakan financial stability yang diproksikan dalam sales to total asset turnover (SATA) berpengaruh signifikan terhadap manajemen laba akrual, diterima. Menurunnya industry, kegagalan bisnis yang meningkat dan turunnya permintaan dari para pelanggan menyebabkan meningkatkan financial distress yang tinggi, keadaan ini akan mendorong manajer untuk melakukan praktik manajemen laba untuk menstabilkan keuangan perusahaan mereka. Hasil penelitian ini konsisten dengan hasil penelitian Ratmono, et all (2014) dan penelitian Deviana Rosita (2014) , Skousen et all (2009) yang menyatakan bahwa financial stability berpengaruh signifikan terhadap manajemen laba akrual. Hipotesis ketiga yang diajukan menyatakan ada pengaruh natur of industry ((RECEIV.) terhadap manajemen laba akrual. Berdasarkan hasil pengujian hipotesis dengan menggunakan uji t, secara parsial natur of industry (RECEIV.) tidak berpengaruh signifikan terhadap manajemen laba akrual pada perusahaan penanaman modal asing yang tercatat di Bursa Efek Indonesia (BEI).

Nature of industry adalah berkaitan dengan munculnya risiko bagi perusahaan yang berkecimpung dalam industri dalam membuat estimasi, memerlukan pertimbangan yang cermat. Faktor risiko yang akan terjadi dalam penilaian piutang mengandung risiko salah saji yang lebih besar bagi perusahaan yang menentukan piutang tak tertagih dengan estimasi. Risiko salah saji estimasi piutang tak tertagih semakin meningkat jika piutang tak tertagih disajikan berdasarkan estimasi manajemen untuk tujuan tertentu. Manajamen dapat memanfaatkan piutang untuk melakukan kecurangan dengan praktik manajemen laba akrual.

Hipotesisketigamenyatakanpeluang(opportunity) dalam natur of industry berpengaruh signifikan terhadap manajemen laba akrual, ditolak. Natur of Industry tidak berpengaruh terhadap perusahaan penanaman modal asing yang tercatat di Bursa Efek Indoneisa menandakan bahwa manajer sangat hati-hati terhadap manajemen piutang dan tidak ingin terjadi salah saji material dalam laporan keuangan mereka. Hasil penelitian ini konsisten dengan hasil penelitian Ardiyani dan Utaminingsih (2015) yang menyatakan natur of industry tidak berpengaruh signifikan terhadap manajemen laba akrual.

Hipotesis keempat yang diajukan menyatakan ada pengaruh rationalization( $A U D C H A N G E$ ) terhadap manajemen laba akrual. Berdasarkan hasil pengujian hipotesis dengan menggunakan uji $\mathrm{t}$, secara parsial rationalization (AUDCHANGE) berpengaruh signifikan terhadap manajemen laba akrual pada perusahaan penanaman modal asing yang tercatat di Bursa Efek Indonesia (BEI).

Rationalization (AUDCHANGE) adalah pergantian Kantor Akuntan Publik yang dilakukan manajemen perusahaan dengan maksud KAP baru belum mengetahui keadaan perusahaan yang sebenarnya, sehingga manajer dapat melakukan praktik manajemen laba. Di Indonesia telah ada regulasi atau peraturan terkait jasa akuntan publik. Pemerintah Indonesia pada tahun 2008 telah menerbitkan Peraturan Menteri Keuangan Nomor 17/PMK.01/2008 yang merupakan peraturan baru tentang jasa akuntan publik yang juga berisi ketentuan pergantian Kantor Akuntan Publik (KAP). Dalam pasal 3 ayat 1 dinyatakan bahwa pemberian jasa audit umum atas laporan keuangan dari suatu entitas dapat dilakukan paling lama 6 (enam) tahun buku berturut-turut oleh KAP yang sama dan 3 (tiga) tahun berturut-turut oleh auditor yang sama kepada satu klien yang 
sama. Jika terdapat perusahaan yang melakukan pergantian KAP secara sukarela dan diluar dari ketentuan yang berlaku tersebut, maka perlu ditinjau apakah ada kecurangan oleh perusahaan (klien) dan ketidaksepakatan antara manajer dan auditor eksternal terkait kebijakan dan praktik akuntansi yang dilakukan perusahaan. Dalam penelitian Hanum (2014), Kurniawati (2012) menyatakan bahwa dengan adanya pengunduran diri atau pergantian auditor, berpotensi adanya kecurangan dalam pelaporan keuangan.

Hipotesis ke empat audit change ( $A U D C H A N G E$ ) berpengaruh signifikan terhadap manajemen laba akrual diterima. Pergantian auditor di perusahaan penanaman modal asing berpengaruh signifikan terhadap manajemen laba akrual. Hasil penelitian ini tidak konsisten dengan hasil penelitian Laila Tiffani (2013), akan tetapi konsisten dengan hasil penelitian skousen et all (2009).

Hipotesis kelima yang diajukan menyatakan ada pengaruh rationalization (TATA) terhadap manajemen laba akrual. Berdasarkan hasil pengujian hipotesis dengan menggunakan uji t, secara parsial rationalization (TATA) berpengaruh signifikan terhadap manajemen laba akrual pada perusahaan penanaman modal asing yang tercatat di Bursa Efek Indonesia (BEI). Berdasarkan nilai thitung 19,203 sedangkan $t$ tabel 1,658, sehingga t hitung lebih besar dari t tabel yaitu 19,203 > 1,658 dengan tingkat signifikansi 0,0000 lebih kecil dari taraf signifikansi 0,05 , maka dapat disimpulkan bahwa Ha diterima dan Ho ditolak.

Francis dan Krishnan (1999) dan Vermeer (2003) berpendapat bahwa prinsip akrual berhubungan dengan pengambilan keputusan manajemen dan memberikan wawasan terhadap rasionalisasi dalam pelaporan keuangan. Menurut Skousen (2009) variabel rasio total akrual dapat digunakan untuk menggambarkan rasionalisasi terkait dengan penggunaan prinsip akrual oleh manajemen.

Hipotesis kelima rationalization (TATA) berpengaruh signifikan terhadap manajemen laba akrual diterima. Rasionalisasi sarat dengan penilaian-penilaian subjektif perusahaan. Penilaian dan pengambilan keputusan perusahaan yang subjektif tersebut akan tercermin dari nilai akrual perusahaan (Skousen et al., 2009). Total akrual akan berpengaruh terhadap manajemen laba akrual karena akrual tersebut sangat dipengaruhi oleh pengambilan keputusan manajemen dalam rasionalisasi laporan keuangan (Beneish,1997). Oleh karena itu, Hasil penelitian ini konsisten dengan penelitian Loe dan Wang (2009) yang menunjukkan variabel rationalization dapat digunakan untuk mendeteksi praktik manajemen laba akrual. Hasil penelitian ini tidak konsisten dengan penelitian Laila Tiffani (2013).

\section{Simpulan, Keterbatasan dan Implikasi Hasil Penelitian}

Penelitian membuktikan pengaruh variabel independen terhadap manajemen laba akrual pada perusahaan penanaman modal asing (PMA) yang terdaftar di Bursa Efek Indonesia selama periode 2010 sampai dengan 2014. Hasil pengujian hipotesis menggunakan regresi berganda. Hasil penelitian ini menunjukkan bahwa:

1. Financial target, Financial Stability, Audit Change, Rationalization berpengaruh signifikan terhadap manajemen laba akrual.

2. Natur of industry tidak berpengaruh signifikan terhadap manajemen laba akrual.

Bagi peneliti lain, perlu penambahan variabel independen disetiap faktor fraud triangle yang sekiranya memiliki hubungan dengan praktik manajemen laba akrual, dengan menambah variabel yang diteliti. Bagi investor disarankan agar mengumpulkan informasi sebanyak-banyaknya, melakukan analisis kemungkinan praktik manajemen laba sebelum memutuskan untuk melakukan investasi. Bagi perusahaan agar memetik pelajaran dari beberapa kasus besar yang menimpa perusahaan yang melakukan praktik manajemen laba akrual yang pada gilirannya akan menyulitkan diri sendiri karena harus menanggung resiko kebangkrutan, resiko hukum dan resiko-resiko lainnya.

\section{Daftar Rujukan}

AICPA, SAS No.99. 2002. Consideration of

Magister Akuntansi Universitas Pancasila 
Fraud in a Financial Statement Audit. New York: AICPA.

AmericanInstituteofCertifiedPublicAccountants (AICPA). 1978. The Commission on Auditors Responsibilities: Report, Conclusions, and Recommendations. New York: AICPA.

Association of Certified Fraud Examiners (ACFE). 2002. "Report to Nation". http:// marketplace. cfenet.com/download.asp.

Association of Certified Fraud Examiners (ACFE). 2000. "Report to Nation " http:// marketplace. cfenet.com/download.asp.

Beasley, M. 1996. An Empirical Analysis of The Relations between The Board of Director Composition and Financial Statment Fraud. The Accounting Review, 71(4), 443-465.

Cressey, D. R. (1953). Other People's Money. Montclair, NJ: Patterson Smith, pp.1-300.

Dechow, Patricia M., Weili Ge, Chad R. Larson, and Richard G Sloan. 2009.Predicting material accounting misstatements. Working Paper. University of California, Berkeley, available at

Gagola, Antonius Stanny Christo. 2011. Analisis Faktor Risiko yang Mempengaruhi Kecenderungan Kecurangan Pelaporan Keuangan Perusahaan Publik di Indonesia. Tesis. Universitas Diponegoro Semarang:Tidak dipublikasikan.

Ghozali, Imam, 2014. Aplikasi Analisis Multivariate Dengan Program SPSS, Edisi Keempat, Penerbit Universitas Diponegoro.

Gusnardi, 2012. Peran Forensic Accounting dalam Pencegahan Fraud. Pekbis Jurnal, Vol 4, No.1, Maret 2012: 17-25. Pekanbaru.

Ikatan Akuntan Indonesia. 2015. Standar Akuntansi Keuangan. PSAK No.1 (Revisi 2015). Jakarta: Penerbit Salemba Empat.

Jensen, M. C., and W. H. Meckling. 1976. Theory of The Firm : Managerial Behaviour Agency Cost and Ownership Structure. Journal of Economics, Vol. 3, No. 4.

Kusumawardhani, Prisca. 2013. Deteksi Financial Statement Fraud dengan Analisis Fraud Triangle pada Perusahaan Perbankan yang Terdaftar Di BEI. Jurnal Universitas Negeri Surabaya, Vol. 1, No. 3.
Loebbecke, J., Eining, M., and Willingham, J. 1989. Auditor's Experience with Material Irregularities: Frequency, Nature, and Detestability. Auditing: A Journal of Practice and Theory, Vol. 9, No. 1.

Lou, Y. and M. Wang. 2009. Fraud Risk Factor of The Fraud Triangle Assesing The Likelihood of Fraudulent Financial Reporting. Journal of Business and Economic Research, Vol. 7, No. 2.

Santoso, Singgih, "Statistik Non Parametrik Konsep dan Aplikasi dengan SPSS", (Jakarta: Penerbit PT. Elex Media Komputindo, 2014) Skousen, J.C., Wright, J.C., Smith Kevin, R. 2009. Detecting and Predicting Financial Statement Fraud: The Effectiveness of The Fraud Triangle and SAS No. 99. Advances in Financial Economics, Vol. 13.

Summers, S. L., and J. T. Sweeney. 1998. Fraudulently Misstated Financial Statements and Insider Trading: an Empirical Analysis. The Accounting Review Vol. 73. No. 1. January. pp 131-146. From https://www. academia.edu/2325157/Fraudulently. misstated financial statements and insider trading An empirical analysis, 13 May 2014.

Tuanakotta, Theodorus M.. 2012. Akuntansi Forensik dan Audit

Investigatif.Jakarta : Penerbit Salemba Empat.

Ujiyantho, Muh. Arif dan Pramuka, B. A. 2007. Mekanisme Corporate Governance, Manajemen Laba, dan Kinerja Keuangan. Prosiding imposium Nasional Akuntansi 10. Makassar.

Wardhani, Ratna. 2009. Faktor-Faktor Penyebab dan Konsekuensi Dari Kecurangan Pelaporan Keuangan (Fraud): Suatu Tinjauan Teoritis. Albrecht, W. S., C. O. Albrecht and C. C. Zimbelman: 2011, Fraud Examination, $4^{\text {th }}$ Edition (Cengage Learning: Mason, Ohio).

Widjaja, Amin. 2011. Pengantar Kecurangan Korporasi. Jakarta: Harvarindo

Magister Akuntansi Universitas Pancasila 